\title{
Erratum to: Are T cells the only HIV-1 reservoir?
}

\author{
Abraham Joseph Kandathil, Sho Sugawara and Ashwin Balagopal ${ }^{*}$
}

\section{Erratum to: Retrovirology (2016) 13:86 DOI 10.1186/s12977-016-0323-4}

Unfortunately, the original version of this article [1] contained an error. Table 1 has errors with the references. The correct Table 1 is found below.

Table 1 Summary data on HIV-1 reservoirs and assays in various cell populations

\begin{tabular}{|c|c|c|c|c|c|c|c|}
\hline & \multirow[t]{2}{*}{ Memory CD4+T cells } & \multicolumn{2}{|l|}{ Myeloid cells } & \multicolumn{2}{|c|}{ Dendritic cells } & \multirow[t]{2}{*}{ FDCs } & \multirow{2}{*}{$\begin{array}{l}\text { Epithelial } \\
\text { cells }\end{array}$} \\
\hline & & Monocytes & Macrophages & pDCs & $\mathrm{mDCs}$ & & \\
\hline Available VOA? & Yes (gold standard) [112] & Yes [24] & Yes [25] & No & No & Yes [87] & No \\
\hline $\begin{array}{l}\text { Has VOA been applied to PLWH taking long- } \\
\text { term ART? }\end{array}$ & Yes (gold standard) [18] & No $[24]$ & Yes [25] & NA & NA & Yes [87] & No \\
\hline $\begin{array}{l}\text { Has HIV-1 been demonstrated in the indicated } \\
\text { cell type in PLWH taking long-term ART? }\end{array}$ & Yes (gold standard) [18] & No [24] & Yes [25] & NA & NA & Yes [87] & Yes $[98,99]$ \\
\hline Is HIV in this reservoir replication competent? & Yes (gold standard) [18] & NA & No & NA & NA & Yes [87] & NA \\
\hline Available animal models? & Yes $[124]$ & Yes $[24,58]$ & Yes $[24,58]$ & Yes [130] & Yes $[130]$ & Yes [85] & No \\
\hline $\begin{array}{l}\text { Have animal models been studied during } \\
\text { long-term ART? }\end{array}$ & Yes [138] & No & No & No & No & No & No \\
\hline $\begin{array}{l}\text { Do animal models with suppressed viremia } \\
\text { contain replication competent HIV-1? }\end{array}$ & Yes [138] & NA & NA & NA & NA & NA & NA \\
\hline Longevity or $T 1 / 2$ of uninfected cells & $1-12$ months $[29,30]^{a}$ & 2-3 days [31] & $\begin{array}{l}\geq 24-36 \text { months } \\
{[32]^{b}}\end{array}$ & $?$ & $?$ & $?$ & $?$ \\
\hline Longevity or $T 1 / 2$ of reservoir in this cell type & 44 months $[18]^{\mathrm{a}}$ & NA & $?$ & $?$ & $?$ & $\begin{array}{l}9 \text { months } \\
{[85]^{c}}\end{array}$ & $?$ \\
\hline
\end{tabular}

\section{? Not known, NA not applicable}

a There are discrepant data on the longevity of uninfected memory CD4+T cells and latent HIV-1 reservoirs therein. However, it is difficult to accurately estimate the $T_{1 / 2}$ of HIV-1 infected T cells due to possible clonal proliferation: i.e., the listed $T_{1 / 2}$ describes the duration of the HIV- 1 reservoir itself, but does not directly address the $T_{1 / 2}$ of the cell that harbors the reservoir

${ }^{b}$ In the described experiments, donor alveolar macrophages were found 2-3 years after lung transplantation in human subjects: while we assume that these TRM persisted for this duration, it is possible that they underwent proliferation and replacement locally

c The indicated longevity is for the infectious virions that were found on FDC dendrites, although it is controversial whether this cell type was actually infected 138 Dinoso JB, Rabi SA, Blankson JN, Gama L, Mankowski JL, Siliciano RF, Zink MC, Clements JE. A simian immunodeficiency virus-infected macaque model to study viral reservoirs that persist during highly active antiretroviral therapy. J Virol. 2009;83(18):9247-57

The online version of the original article can be found under doi:10.1186/s12977-016-0323-4.

Published online: 08 February 2017

*Correspondence: abalago1@jhmi.edu

Department of Medicine, Johns Hopkins University Baltimore, 855 N. Wolfe Street, Rm. 535, Baltimore, MD 21025, USA

\section{Reference}

1. Kandathil AJ, Sugawara S, Balagopal A. Are T cells the only HIV-1 reservoir? Retrovirology. 2016;13:86. doi:10.1186/s12977-016-0323-4. 